\title{
A RESEARCH ON HOW TO IMPLEMENT REMOTE EXPERIMENTS TO PRIMARY SCHOOL EDUCATION
}

\author{
Michaela KOSTELNÍKOVÁ - Miroslava OŽVOLDOVÁ
}

\begin{abstract}
Slovak students have problems to apply theory in practice. To change this situation we have to change the ways of the transfer of knowledge. Activating methods appear to be a good choice. In the paper, a concrete example of the implementation of the activating methods via three remote experiments (online meteorological stations) (http://remotelab1.truni.sk, http://experimenta.fe.up.pt/ estacaometeorologica/index.php?lang=pt, http://kdt-16.karlov.mff.cuni.cz/en/mereni.html) and project method is described. Furthermore, a pedagogical research on a sample of 156 primary school students is analyzed. It is a continuation of the previous pilot research and it's still going on. The results of the first didactic tests and a questionnaire are presented and discussed. It turns out that students actively involved in the work with the remote experiments get a higher score on tasks of a practical work with data.
\end{abstract}

Key words: real remote experiments, research, project method, didactic test, questionnaire.

\section{VÝSKUM SO ZAMERANÍM NA IMPLEMENTÁCIU REÁLNYCH VZDIALENÝCH EXPERIMENTOV DO VYUČOVANIA NA ZÁKLADNEJ ŠKOLE}

Resumé: Slovenskí študenti majú t’ažkosti s aplikáciou teórie do praxe. Aby sme mohli zmenit' túto situáciu, musíme prehodnotit’ a upravit' spôsob prenosu poznatkov v edukačnom procese. Aktivizujúce metódy sa javia byt' tou správnou vol'bou. $V$ príspevku prezentujeme konkrétny príklad implementácia aktivizujúcich metód do edukácie prostredníctvom projektu s podporou troch vzdialených experimentov (online meteorologických staniciach) (http://remotelab1.truni.sk, http://experimenta.fe. up.pt/estacaometeorologica/index.php?lang=pt, http://kdt-16.karlov.mff.cuni.cz/en/mereni.html). Následne predkladáme výsledky pedagogického výskumu, ktorý sme zrealizovali na vzorke 156 žiakov základných škôl. Výskum je pokračovaním pilotného šetrenia a nad’alej prebieha. Prezentujeme a analyzujeme výsledky prvých didaktických testov a dotazníka. Z výsledkov vyplýva, že žiaci, ktorí aktívne pracovali so vzdialenými experimentmi - online meteorologickými stanicami - dosiahli vyššie skóre v úlohách zameraných na prácu s dátami.

Klíčová slova: reálny vzdialený experiment, výskum, projektová metóda, didaktický test, dotazník.

\section{Introduction}

The last two international measurements of the quality of knowledge - PISA - revealed many weak points in the Slovak students' knowledge (Koršňáková, Kováčová, Heldová, 2010; Ožvoldová, 2010). The most obvious problem is the lack of practical thinking among our students. One of the possible solutions of the current situation is to support new forms and methods of education in the teaching-learning process. It is desired to promote the types of methods that activate students. In the field of Science (Physics, Chemistry and Biology) inquiry-based learning is the proper way how to bring the active knowledge acquisition via simple experiments back to education process (Wosilait et al., 1998). Wieman and Perkins (2005) are the advocates of this idea. They realize it via the implementation of interactive simulations to education.

The development of information and communication technologies brought a new possibility of experimentation via remote access across the Internet. In our Department of Physics at Trnava University we deal with the design and realization of real remote experiments. Our effort led to the launch of the first Slovak natural science e-laboratory free available on http://kf.truni.sk/remotelab.

This work presents the implementation of the chosen remote experiments by means of a project to primary school physics education. The paper is organized as follows: the section 'Real remote experiments' acquaints with remote experimentation, the section 'The pedagogical experiment' provides the details of the research, the section 'Results' presents the statistical 
results gained, and the section 'Conclusions' summarizes the results and illustrates the future work.

\section{Real remote experiments}

A remote experiment (RE) is a real experiment with real laboratory instruments and equipment that can be controlled by a user from his/her computer through the Internet. We can run this experiment from every place around the world, change the values of adjustable quantities and, after the measurement, we can import the experimental data into our computer. Some of the real e-laboratories are accessible to all the users 24/7 (Ožvoldová, Žovínová, 2011).

The implementation of REs to science education is supported by the following findings:

- Physics belongs to unpopular subjects and one of the reasons is the lack of experiments implemented to education process (Wieman, Perkins, 2005);

- The presence of the experiments in the Physics classes influences the students' positive attitude to the subject (Yeşilyurt, 2002);

- The active involvement of the students via experimentation increases their conceptual knowledge (Thorton, Sokoloff, 1998);

- Education supported by interesting electronic means leads to the reduction of negative attitudes to Physics (Záhorec, Hašková, 2009). Other reasons for the implementation of remote experiments to education are these benefits:

- Saving time, space and money;

- Motivating students to "play with" or operate the real apparatus via the Internet;

- Providing distance education, an option also for physically-challenged students (Nickerson et al., 2007);

- Demonstrating the kinds of experiments that could not be conducted in a school laboratory (e.g. proving that the acceleration due to gravity is not constant on the Earth).

Although the REs are relatively familiar to many teachers, their usage at secondary or even primary schools is rare. We've provided a small survey among Slovak primary and secondary school Physics teachers. Figure 1 shows they use different types of experiments, but none of them is familiar with the use of REs in their practice.

We carry out various activities to inform teachers about the possibilities of remote experimentation because it is very important to start with active involvement of students at primary school. Here pupils develop their attitude to particular subjects. It is very difficult to gain the secondary school students for the further study of Physics if they have no positive experience from primary school. And experimentation in all forms can be very motivating. In the paper, one of the possibilities of the implementation of REs to primary school education is shown.

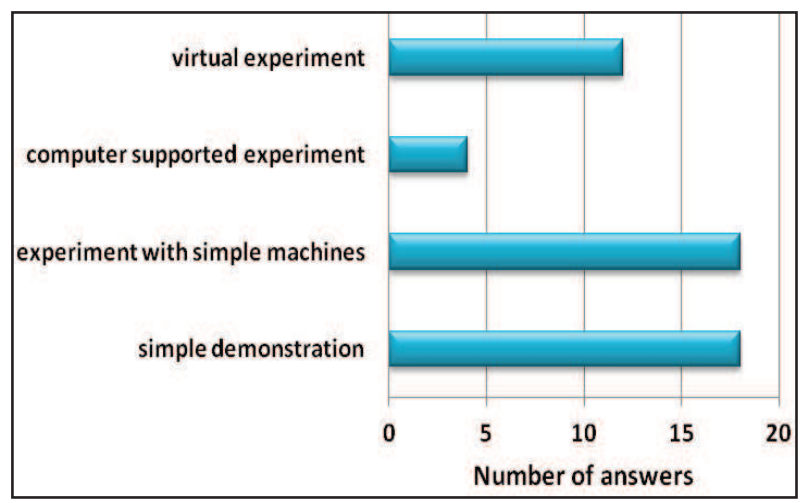

Fig 1: The graph representing the types of experiments used in the education process

\section{The pedagogical experiment}

We've designed and realized the project "Measuring air temperature in different EU countries" with the support of three online meteorological stations located in Trnava, Slovakia (http://remotelab1.truni.sk), Prague, Czech Republic (http://kdt-16.karlov.mff.cuni.cz /en/mereni.html), and Porto, Portugal (http://experimenta.fe.up.pt/estacaometeorologica /index.php? lang=pt) The main goals of the research were:

- to explore the correlation between the implementation of the remote experiments to the education process at primary school and the acquired knowledge of students;

- to explore the correlation between the implementation of the remote experiments to the education process at primary school and the attitudes of students to Physics.

We set the following hypotheses and research questions:

H1: The students acquiring knowledge via the active experimentation across the Internet will have significantly higher post-test scores than students who are taught in the traditional way.

H2: The students acquiring knowledge via the active experimentation across the Internet will gain better knowledge and skills in the 
analysis of experimental data than students who are taught in the traditional way.

Q1: Is there some statistically significant correlation between the results of the post-test of test group and gender?

Q2: Do the students participating in the work on the project have positive attitude to active experimentation across the Internet?

The participants in the research were 156 seventh-grade Slovak primary school students
(69 males and 87 females). They formed two separate groups - test group (TG) and control group (CG). A pedagogical experiment was designed, in which the independent variable was the work on the project and the dependent variables were the knowledge of the students and the attitudes of the students to Physics. It took place at six primary schools. Figure 2 shows the individual steps of the pedagogical experiment.

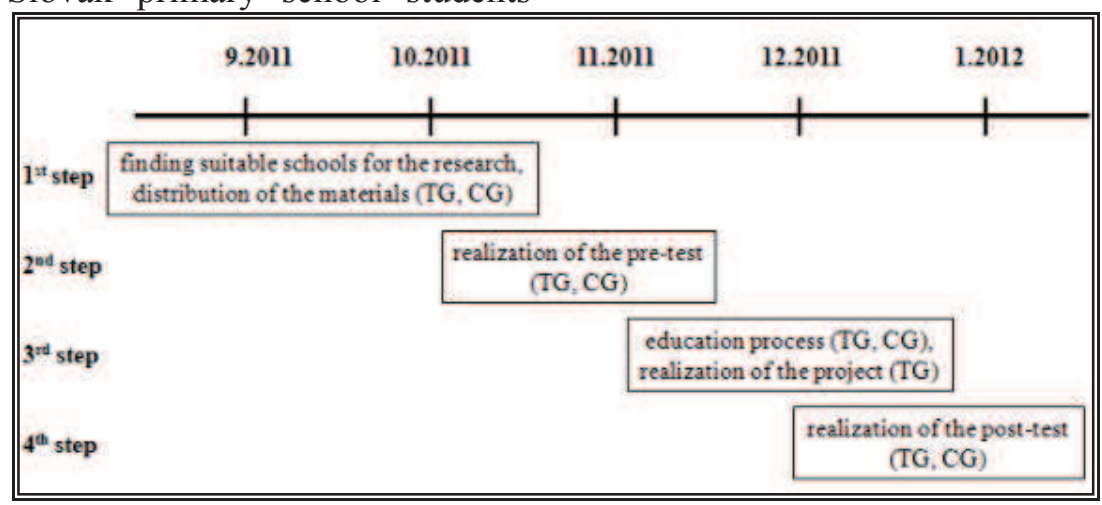

Fig 2: The course of the pedagogical experiment

CG working with REs had to fulfil following assignments:

- To choose the period of two weeks for data collection;

- To collect the data on the air temperature (with an appropriate sampling period - e.g. every six hours) and arrange them in a table;

- To plot the corresponding time dependence of the air temperature;

- To explore the changes in the temperature and to identify the maxima and minima;

- To calculate the average value of the temperature; to identify the greatest difference between the maximum and minimum of the day temperature;

- To show the independent and dependent quantities;
- To denote the average value of the temperature in the graph;

- To introduce the particular country from the point of view of its latitude;

- To compare the data obtained with the data of other groups;

- To explore the relation between the temperature and the latitude (Žovínová, Ožvoldová, 2011)

\section{Results}

For the statistical evaluation of data we used SPSS software. The results gained during the research are summarized in Table 1 and Table 2.

\section{Pre-test}

All data were initially analyzed to prove the Gaussian distribution with the KolmogorovSmirnov normality test (see Table 1).

Tab 1: The results of the pre-test, the post-test and the post-test-work with data

\begin{tabular}{|c|c|c|c|c|c|c|}
\hline & \multicolumn{2}{|c|}{ Pre-test } & \multicolumn{2}{|c|}{ Post-test } & \multicolumn{2}{|c|}{ Post-test - Data } \\
\hline & TG & CG & TG & CG & TG & $\mathrm{CG}$ \\
\hline Mean & 17,646 & 17,551 & 15,373 & 13,709 & 6,873 & 5,589 \\
\hline Std. Deviation & 3,914 & 4,315 & 4,448 & 4,806 & 2,369 & 2,653 \\
\hline Kolmogorov-Smirnov Z & 1,614 & 1,563 & 0,909 & 0,673 & 1,344 & 1,086 \\
\hline K-S p-value & 0,011 & 0,015 & 0,380 & 0,756 & 0,054 & 0,189 \\
\hline $\begin{array}{l}\text { Mann-Whitney (Wilcoxon W) } \\
\text { M-W p-value }\end{array}$ & \multicolumn{2}{|c|}{$\begin{array}{c}6149,500 \\
0,648\end{array}$} & \multicolumn{2}{|c|}{ 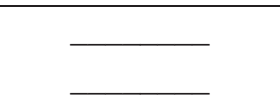 } & \multicolumn{2}{|c|}{$\longrightarrow$} \\
\hline $\begin{array}{l}\text { t-test } \\
\text { t-test p-value }\end{array}$ & \multicolumn{2}{|c|}{ 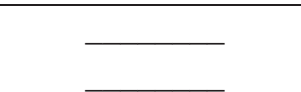 } & \multicolumn{2}{|c|}{$-2,259$} & 0,002 & $-3,211$ \\
\hline
\end{tabular}


We tested the null hypothesis:

$\mathrm{H}_{0}$ : The distribution of the results of the pre-test is normal.

Since the p-values of $\mathrm{TG}$ and $\mathrm{CG}$ were smaller than the level of significance $\alpha=0,05$, we rejected the normality assumption.

For the comparison of the results of TG and CG we used nonparametric two-tailed MannWhitney test. We tested the null hypothesis:

$\mathrm{H}_{0}$ : There is no significant difference between the results of the pre-test of TG and CG.

Since the $p$-value $p=0,648$ was greater than the level of significance, we verified the similar prior knowledge of the students. Figure 3 shows the results of the pre-test in the graphical form.

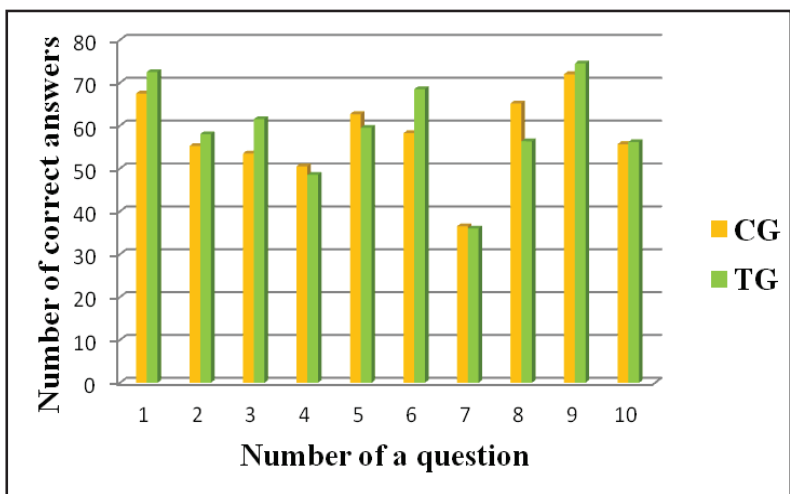

Fig 3: The results of the particular questions from the pre-test

\section{Post-test}

The post-test consisted of two parts: theoretical (questions $1-9$ ) and practical (questions $10-15)$ (work with data). We evaluated the whole test and the second practical part individually.

We followed the same steps as in the case of the statistical evaluation of the pre-test.

Because of the normality of distribution, for the comparison of the results of TG and CG we used parametric t-test.

We proved the significant difference between the results of TG and CG. TG had significantly better results of the post-test. These results prove the validity of the hypothesis H1.

\section{Post-test - work with data}

Parametric t-test proved the significant difference between the results of TG and CG. TG had significantly better results of the part Work with data. These results prove the validity of the hypothesis H2. Figure 4 shows these results in the graphical form. TG dominated in all the questions focused on the application of knowledge.

\section{The results of the tests of $T G$ and gender}

To answer the research question Q1 we tested the results of the pre-test and the post-test for girls and boys individually (see Table 2).

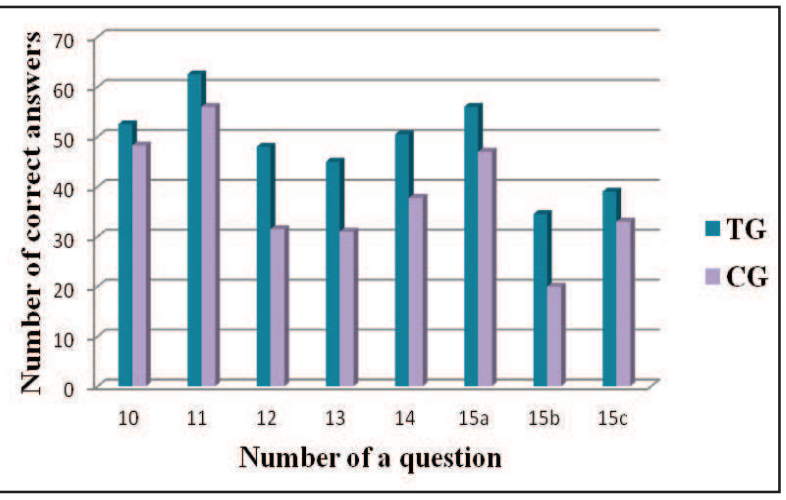

Fig 4: The results of the particular questions from the post-test - work with data

For the comparison of the results of girls and boys of TG we used parametric t-test. The $\mathrm{p}$-values of all t-tests were greater than the level of significance $\alpha=0,05$. Although girls had a little higher test scores, we can answer the research question Q1 as follows: There is no statistically significant correlation between the results of the post-test of the test group and gender.

Tab 2: The results of the statistical tests for pre-test, post-test and post-test - work with data

\begin{tabular}{|l|cc|cc|cc|}
\hline \multirow{2}{*}{ Mean } & \multicolumn{2}{|c|}{ Pre-test } & \multicolumn{2}{c|}{ Post-test } & \multicolumn{2}{c|}{ Post-test - Data } \\
\cline { 2 - 8 } Std. Deviation & Girls & Boys & Girls & Boys & Girls & Boys \\
\hline Kolmogorov-Smirnov Z & 18,128 & 16,938 & 15,870 & 14,682 & 7,196 & 6,424 \\
K-S p-value & 3,666 & 4,212 & 4,455 & 4,412 & 2,337 & 2,375 \\
\hline t-test & 1,290 & 0,917 & 0,821 & 0,630 & 1,236 & 0,806 \\
t-test p-value & 0,072 & 0,370 & 0,510 & 0,823 & 0,094 & 0,534 \\
\hline
\end{tabular}




\section{The results of the questionnaire}

Before the end of the project work the students of TG completed the questionnaire consisting of 16 questionnaire items. These were aimed at exploring students' relation to the Internet, their way of the realization of the project and the benefits of the project (Žovínová, Ožvoldová, 2011).

The total number of respondents was 79 (48 females and 31 males). 92,4\% of them have a computer with the Internet at home, so they could work on the assignments comfortably at home. In the following we present the results connected with the research questions Q2 and Q3.

One of the goals of the questionnaire was to identify the benefits of the project from the point of view of the students. We also wanted them to identify the tasks that were problematic. Figure 5 shows three most frequent answers:

Benefits:

- to make a graph and a table;

- cooperation with other students.

Problems:

- to make a graph and a table;

- they had no problems with the assignment.

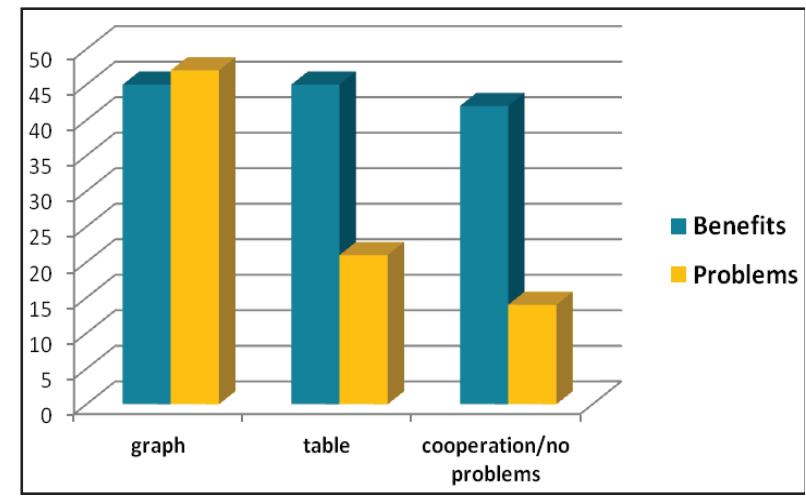

Fig 5: The benefits of the project and the problems during the work on the project

It is obvious graphs and tables were considered to be the most beneficial for students as well as the most problematic tasks. It is because this was their first touch with such a huge packet of data and they were not used to work with it. But the results of the post-test proved this confrontation was conducive to train them in the data analysis.

We also wanted to find out if the students liked the work on the project and the experimentation across the Internet (Figure 6). In the pilot research, $66 \%$ of the respondents liked the work on the project and $38 \%$ of them wanted to do another one. We expected similar results from this year. Instead we observed a positive shift in students' views. We are pleased to note that more than the half of the students $(58,2 \%)$ wanted to do another project and only $17,7 \%$ of the students didn't like the work with the remote experiments.

On the basis of the results, we can answer Q2 it as follows: The students participating in the work on the project have positive attitude to active experimentation across the Internet.

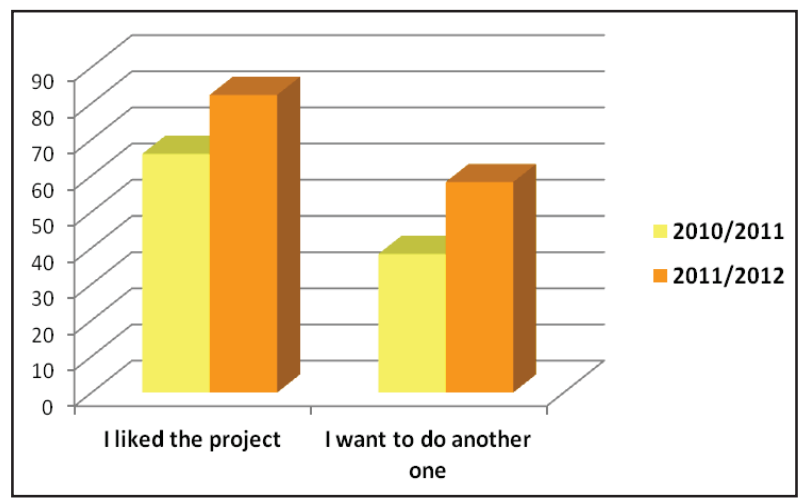

Fig 6: The comparison of the students' views from the previous and this year (in percentage)

\section{Conclusions}

In the paper, the implementation of REs to the education via the project assignment was presented. We've managed to develop not only physics knowledge, but also the field of ICT, Mathematics, Geography, Foreign language or Art. The main conclusions of the presented work may be formulated as follows:

- For the first time REs were integrated to the primary school physics education in Slovakia;

- The pilot research on the implementation of three remote meteorological stations to the physics education was realized;

- On the basis of the pilot research the pedagogical experiments was realized;

- On a sample of 156 primary school students results were gained as follows:

- There is no significant difference between test scores of the pre-test of TG and CG;

- The students in TG had significantly higher test scores of the post-test;

- They dominated in all the questions where the application of knowledge was essential;

- There is no significant correlation between the test scores of girls and boys in TG; 
- The students expressed an affirmative attitude to remote experimentation - we observed a positive shift compared to the results from the pilot research.

- According to students' opinion not only knowledge and skills were the benefits of the project, but also the chance to cooperate with other classmates, discuss some problems and look for the proper solutions.

We can note the goals of the research were completed and the results gained in the pedagogical experiment support other implementation of remote experiments to education process. The research is going on, other projects are implemented to primary school education process and we also plan to explore the durability of students' knowledge.

\section{References}

[1] COOPER, M. 2005. Remote laboratories in teaching and learning - issues impinging on widespread adoption in science and engineering education. In. International Journal of Online Engineering (iJOE). Vol. 1, No. 1, ISSN: 18612121.

[2] KORŠŇÁKOVÁ, P., KOVÁČOVÁ, J., HELDOVÁ, D. 2010. Národná správa OECD PISA Slovensko 2009. Bratislava: Národný ústav certifikovaných meraní vzdelávania. $60 \mathrm{p}$. ISBN 978-80-970261-4-1.

[3] NICKERSON, J., CORTER, J, ESCHE S., AND CHASSAPIS, C. 2007. A model for evaluating the effectiveness of remote engineering laboratories and simulations in education. In: Computers $\square$ Education. UK: Elsevier Science Ltd., 2007, pp. 708-725, ISSN 0360-1315.

[4] OŽVOLDOVÁ, M. 2010. Je výučba prírodných vied v kríze? Ako d’alej? In Acta Fac. Paed. Univ. Tyrnaviensis, Ser. C. Trnava: University of Trnava, 2010, pp. 49-68, ISBN 978-80-8082-432-7.

[5] OŽVOLDOVÁ, M. et al. 2011. 1st Slovak natural sciences e-laboratory. In. Obzory matematiky, fyziky a informatiky. Vol. 40, No. 2. ISSN 1335-4981, pp. 31-37.

[6] OŽVOLDOVÁ, M., ŽOVÍNOVÁ, M. 2011. Integrated e-Learning Demonstrated with Free Fall e-Experiment. In. E-learning, Distance Education... or the Education of 21st Century.
Sofia, Bulgaria : Izdatelstvo Demetra EOOD. ISBN 978-954-9526-75-2, pp. 154-161.

[7] THORNTON R. K., SOKOLOFF D. R. 1998 Assessing student learning of Newton's laws: The Force and Motion Conceptual Evaluation and Evaluation of Active Learning Laboratory and Lecture Curricula. In. Amer. J. of Physics, Vol. 66, No. 4. ISSN 0002-9505, pp. 338-352.

[8] WIEMAN, C., PERKINS, K. 2005. Transforming physics education. In: Physics Today, vol. 58, 2005, pp. 36-41, ISSN 00319228.

[9] WOSILAIT, K., HERON, P. R. L., SHAFFER, P. S. AND MCDERMOTT, L. C. 1998. Development and assessment of a researchbased tutorial on light and shadow. In. Am. J. Phys., Vol. 66, No. 10. ISSN 0002-9505, pp. 906-913.

[10] YEŞILYURT, M. 2002. Student teachers' attitudes about basic physics laboratory. In: TOJET, vol. 3, 2002, pp. 49-57, ISSN 1303 6521.

[11] ZÁHOREC, J. HAŠKOVÁ, A. 2009. Empirical research of influencing students' attitudes towards teaching subjects by multimedia teaching materials. In: JTIE. Olomouc: Univerzita Palackého, 2009, pp. 69 - 76, ISSN 1803-6805.

[12] ŽOVÍNOVÁ, M., OŽVOLDOVÁ, M. 2011. Remote experimentation at primary school. In HSCI 2011: Proceedings of the 8th International Conference on Hands-on Science Focus on Multimedia, September 15 to 17, 2011, University of Ljubljana, Slovenia. Slovenia: University of Ljubljana. ISBN 978-989-95095-73 , pp. 110-114.

\section{Mgr. Michaela Kostelníková}

doc. RNDr. Miroslava Ožvoldová, CSc.

Katedra fyziky

Pedagogická fakulta Trnavskej univerzity

Priemyselná 4, 91843 Trnava, SR

Tel: +421905 847201

\& Fakulta aplikovanej informatiky

Univerzita Tomáše Bati

Nad Stráněmi 4511, 76005 Zlín, CZ

E-mail: zovinova.michaela@centrum.sk mozvoldo@truni.sk

http://kf.truni.sk, http://kf.truni.sk/remotelab 